\title{
Critical Review on Efficiency of Ground Heat Exchangers in Heat Pump Systems
}

\author{
Adel Eswiasi ${ }^{1}$ and Phalguni Mukhopadhyaya ${ }^{2, *(1)}$ \\ 1 Department of Mechanical Engineering, Faculty of Engineering, University of Victoria, 3800 Finnerty Road, \\ Victoria, BC V8W 2Y2, Canada; aeswiasi@uvic.ca \\ 2 Department of Civil Engineering, Faculty of Engineering, University of Victoria, 3800 Finnerty Road, \\ Victoria, BC V8W 2Y2, Canada \\ * Correspondence: phalguni@uvic.ca
}

Received: 6 May 2020; Accepted: 10 June 2020; Published: 19 June 2020

\begin{abstract}
Use of ground source heat pumps has increased significantly in recent years for space heating and cooling of residential houses and commercial buildings, in both heating (i.e., cold region) and cooling (i.e., warm region) dominated climates, due to its low carbon footprint. Ground source heat pumps exploit the passive energy storage capacity of the ground for heating and cooling of buildings. The main focus of this paper is to critically review how different construction and operation parameters (e.g., pipe configuration, pipe diameter, grout, heat injection rate, and volumetric flow rate) have an impact on the thermal efficiency of the vertical ground heat exchanger (VGHE) in a ground source heat pump (GSHP) system. The published literatures indicate that thermal performance of VGHEs increases with an increase of borehole diameter and/or pipe diameter. These literatures show that the borehole thermal resistance of VGHEs decreases within a range of $9 \%$ to $52 \%$ due to pipe configurations and grout materials. Furthermore, this paper also identifies the scope to increase the thermal efficiency of VGHE. The authors conclude that in order to enhance the heat transfer rate in VGHE, any attempt to increase the surface area of the pipe configuration would likely be an effective solution.
\end{abstract}

Keywords: vertical ground heat exchangers; thermal response test; borehole thermal resistance

\section{Introduction}

In a world under climate change emergency, the importance of eco-friendly renewable energy as a replacement of fossil fuel based energy cannot be overemphasized. Residential houses and commercial buildings are considered to be the main consumers of energy in the world, which are responsible for $15 \%$ to $30 \%$ of the total world energy consumption. The same amount of greenhouse gases is also produced and emitted to the environment due to fossil fuel combustion [1]. Geothermal energy is one of the cleanest sources of renewable energy that can be used to produce electricity and heat. Geothermal energy resources are divided into three different categories: (i) high temperature $\left(>150{ }^{\circ} \mathrm{C}\right)$ resources used to produce electricity, (ii) moderate temperature $\left(<150{ }^{\circ} \mathrm{C}\right)$ resources used for direct applications, and (iii) low temperature $\left(<32^{\circ} \mathrm{C}\right)$ resources used to support heat pumps for heating and cooling buildings [2]. Geothermal is considered as the fifth biggest source of renewable energy and is available across the world [3,4]. Ground source heat pump (GSHP) systems, consisting of heat pumps and ground heat exchangers, is a source of renewable energy in both cold and warm climates. This technology is employed to extract the heat from buildings in summer and transfer into the ground, as well as in winter to extract the heat from the ground and transfer into the buildings. Ground source heat pump systems can be equipped with two types of ground heat exchangers: (i) Vertical, and (ii) Horizontal. Vertical ground heat exchangers have many advantages over horizontal 
ones, such as higher energy efficiency and a much smaller area required for installation. However, both vertical and horizontal systems provide a clean energy exchange operation that exploits the thermal energy storage capacity of the underground soil and reduces or eliminates the fossil fuel-based energy consumption in buildings. The amount of heat transferred between the heat carrier fluid and ground determines the efficiency of the ground source heat pump systems. Various researchers used analytical, experimental, and numerical studies to devise ways for improving the heat transfer rate between the VGHE and the ground. The aim of this paper is to review the published literatures on various options, including pipe configurations, to improve the efficiency of ground heat exchangers.

\subsection{Research Background}

A ground source heat pump system consists of a heat pump and one or multiple borehole ground heat exchanger/s that are coupled together to transfer the thermal energy between the ground and buildings as shown in Figure 1. The heat pump consists of five major components, including a compressor, an expansion valve, two heat exchangers (evaporator and condenser), and a reversing valve. In addition, there are other accessories, for example pipes, a fan in the air heat exchanger (condenser), and controls [5]. In heating dominated climates, the evaporator heat exchanger is coupled with the vertical ground heat exchanger to exchange the heat while the condenser heat exchanger exchanges heat with space. Ground heat exchangers generally consist of two types: (1) Open, and (2) Closed systems.

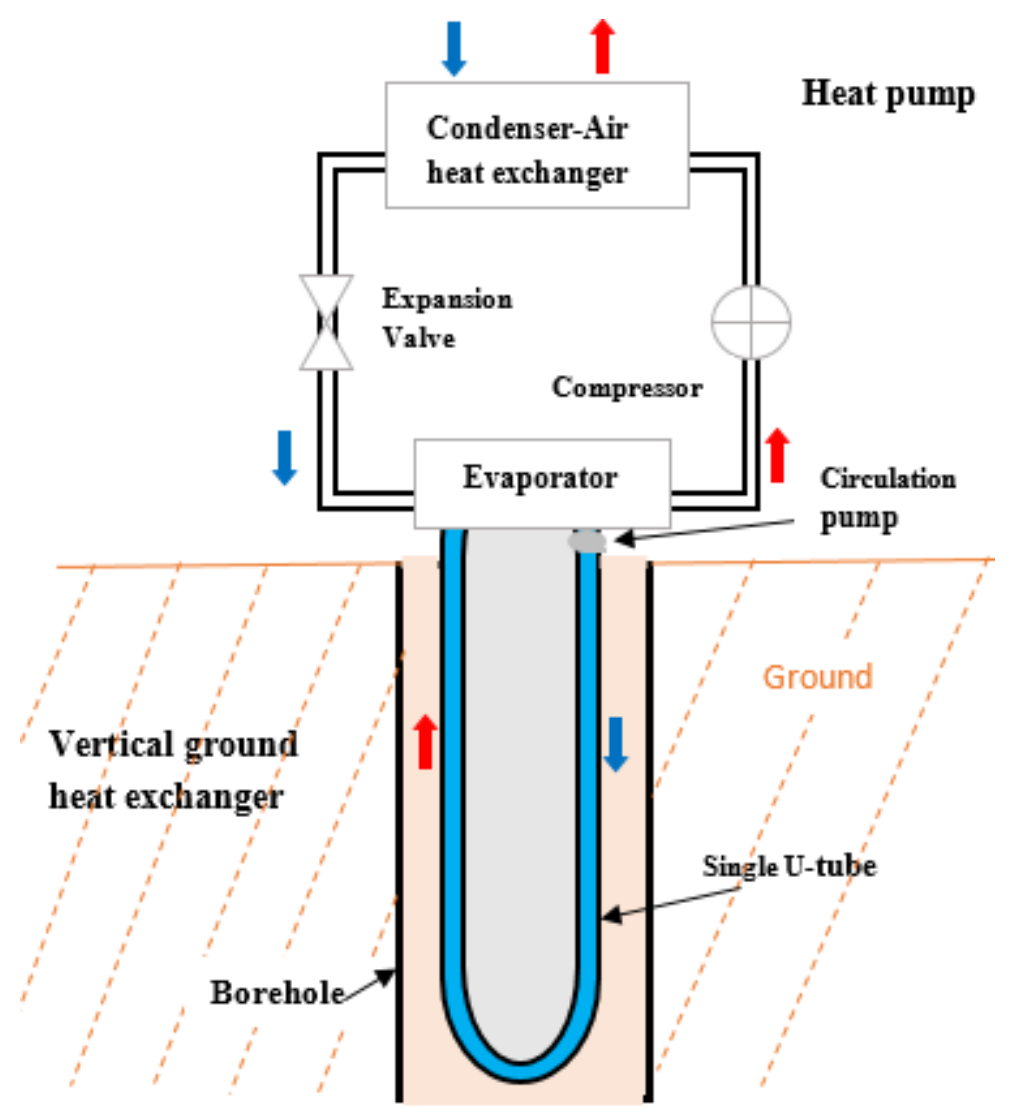

Figure 1. Ground source heat pump system (in heating-dominated climate).

\subsubsection{Open System}

The open system uses a heat source, such as a well, lake, or river as a ground heat exchanger. The groundwater is pumped into the heat pump to exchange the heat and then the groundwater returns to the ground as shown in Figure 2. 


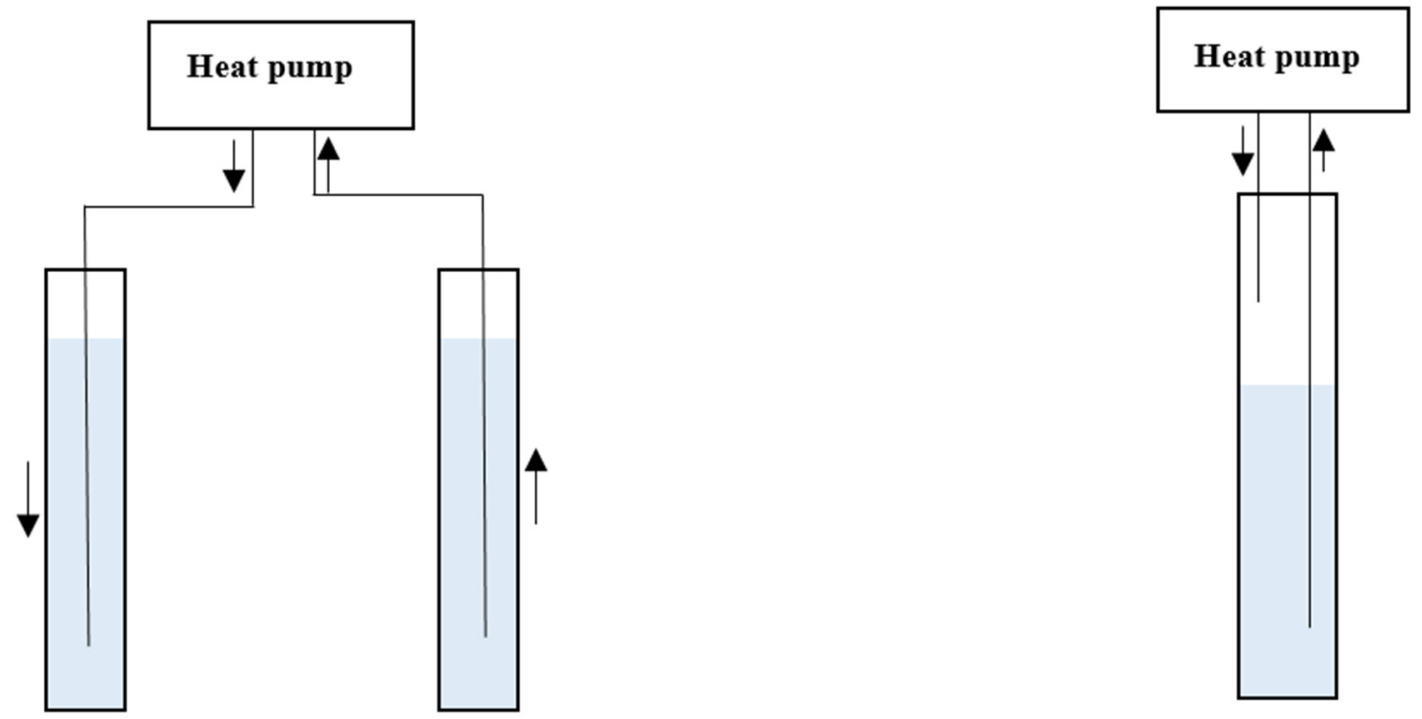

Figure 2. Schematics of different open ground heat exchangers.

\subsubsection{Closed System}

The closed system can also use heat source, such as a well, lake, or river, as a ground heat exchanger. However, in a closed system, the heat carrier fluid is circulated through a close-loop ground heat exchanger to transfer the thermal energy between the ground and the heat pump unit (Figure 3). There are three types of ground heat exchangers (horizontal, vertical, and pond/lake) as shown in Figure 3. Figure 4 shows the cross section of the commonly used vertical heat exchanger designs.
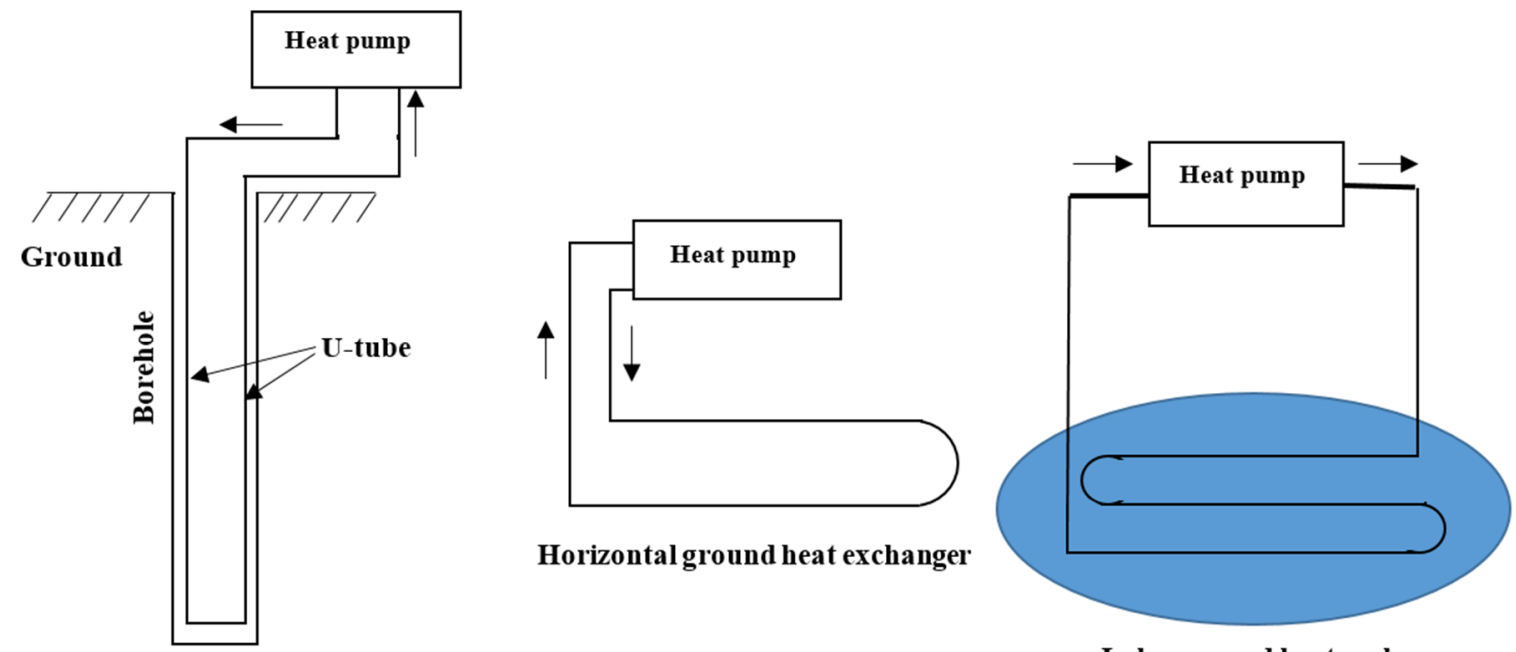

Vertical ground heat exchanger

Lake or pond heat exchanger

Figure 3. Schematics of different closed ground heat exchangers [6]. 


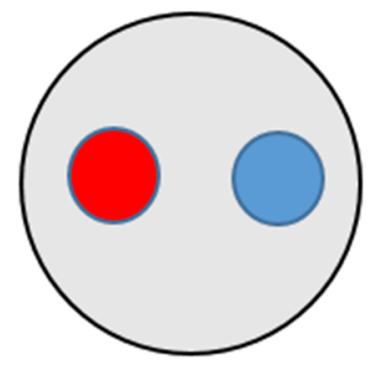

Single U-tube

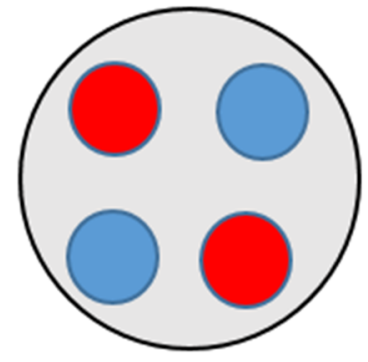

Double U-tube

Figure 4. Cross section of the commonly used vertical heat exchanger designs.

\subsubsection{Borehole Thermal Resistance}

A heat exchanger inserted into a vertical or horizontal borehole is termed a borehole heat exchanger, and borehole thermal resistance is an important parameter for both steady state and transient heat transfer analysis. The borehole thermal resistance is a function of the mean temperature of the heat carrier fluid in the legs of the U-tube and the borehole wall temperature. The steady state thermal resistance of the borehole can be defined by the Equation (1) [7]:

$$
q=\frac{\left(T_{f}-T_{b}\right)}{R_{b}}
$$

where $T_{f}$ is the mean temperature of the heat carrier fluid in the legs of the U-tube $(\mathrm{K}), T_{b}$ is the temperature on the borehole wall $(K), R_{b}$ is the borehole thermal resistance $(\mathrm{W} / \mathrm{m} \cdot \mathrm{K}), q$ is a specific heat rate (heat transfer rate per unit length of borehole) $(\mathrm{W} / \mathrm{m})$.

The borehole heat exchanger consists of three components: (1) fluid, (2) pipe, and (3) grout material, as shown in Figure 5. The borehole resistance can be expressed as shown in the following equation:

$$
R_{b}=R_{f}+R_{p}+R_{g}
$$

where $R_{f}$ is fluid thermal resistance $(\mathrm{W} / \mathrm{m} \cdot \mathrm{K}), R_{p}$ is pipe wall thermal resistance, and $R_{g}$ is grout thermal resistance $(\mathrm{W} / \mathrm{m} \cdot \mathrm{K})$.

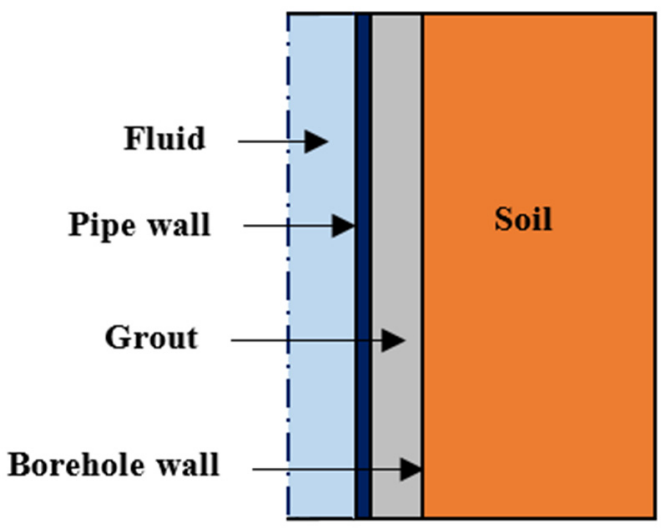

Figure 5. Thermal resistance in borehole ground heat exchanger. 


\subsubsection{Thermal Response Test}

Thermal Response Test (TRT) is the most widely used method to assess the influence of ground properties (e.g., thermal conductivity of the underground soil, thermal resistance of the borehole, etc.) on the performance of the borehole ground heat exchanger [8-11]. In this method, the inlet $\left(T_{i n}\right)$ and outlet $\left(\mathrm{T}_{\text {out }}\right)$ fluid temperature data are analyzed. The first thermal response test in the field was performed to estimate the thermal resistance of the heat carrier fluid and the borehole wall, and thermal conductivity of the ground [8]. A first mobile thermal response test device was constructed at the University of Lulea in Sweden [9]. In 1996, they also developed a mobile response test device to estimate the thermal conductivity of the ground as well as the impact of natural convection and flow of the groundwater in the boreholes. A similar experimental device was developed at the Oklahoma State University to estimate the ground thermal properties [10]. In 2000, the first field thermal response test was performed in Germany [11].

\section{Literature Review}

Various researchers conducted studies to understand the ground heat transfer behavior in and around the vertical ground borehole heat exchangers. These research studies (numerical and experimental (including laboratory and field studies)) focus on a number of issues related to the measurement and analysis of performance of ground heat exchangers, and could be broadly classified into four different categories:

1. Effects of grout materials on the thermal performance of ground heat exchangers,

2. Influence of different pipe configurations on the thermal performance of ground heat exchangers,

3. Effects of borehole depths and diameters on the thermal performance of ground heat exchangers, and

4. Miscellaneous issues related to performance of ground heat exchangers (e.g., ground heat transfer characteristics calculation methods; recovery time; performance in arctic/cold climate etc.)

\subsection{Effects of Grout Materials on the Thermal Performance of Ground Heat Exchangers}

Laboratory and field studies were performed to determine how several variables such as grout thermal conductivity, borehole diameter, pipe size, and pipe configuration could impact the total thermal resistance in the borehole. Laboratory study indicated that an increase in the thermal conductivity of grout reduced the borehole thermal resistance. However, there was very small additional reduction of the thermal resistance produced when grout thermal conductivity was above $1.73 \mathrm{~W} / \mathrm{m} \cdot \mathrm{K}[12]$.

Laboratory studies were undertaken to study the effects of the thermal conductivity of cementitious grouts with various fillers on borehole thermal resistance. It was reported that decreasing the water-cement ratio and addition of conductive filler significantly increased the grout thermal conductivity. In the dry condition, superplasticizer cement-sand grout had a higher thermal conductivity than bentonites and neat cements. Several grouts were tested to determine how different grouts allow for the decrease of the length of the borehole, resulting in cost savings and improved performance. Theoretical studies predicted that the length of the borehole decreased by $22-37 \%$ when the cement-sand grouts were used in the borehole heat exchanger in place of commonly used granular bentonite-water mixes [13].

Four types of soils were tested in the laboratory to estimate the impact of bulk density and moisture content on the thermal conductivity of some Jordanian soils. The four types of soils were sand, sandy loam, loam, and clay loam. The results showed that the thermal conductivity increased with the increase of soil density and moisture content. In addition, it was also observed that the thermal conductivity of sandy soil was higher than the clay loam soil. In this study, the thermal conductivities calculated using the cooling data were found to be lower than the same calculated using the heating data [14]. 
A number of thermal response tests were conducted to study the impact of different types of grout materials on the thermal performance of double U-pipe ground heat exchangers (GHEs). Figure 6 shows the cross section of double U-pipe ground heat exchanger with spacer. Four different types of grout materials: (1) bentonite, (2) bentonite with spacers, (3) $50 \%$ sand and bentonite with spacers, and (4) Quartz sand with spacers were used during these thermal response tests. The results showed that the borehole thermal resistance of the double U-pipe ground heat exchanger with quartz sand and spacers was $30 \%$ lower compared to when bentonite with spacers was used as grout. It was also noticed that the thermal resistance values for the double U-tube GHE with and without spacers were 0.141 and $0.143 \mathrm{~m} \cdot \mathrm{K} / \mathrm{W}$, respectively [15].

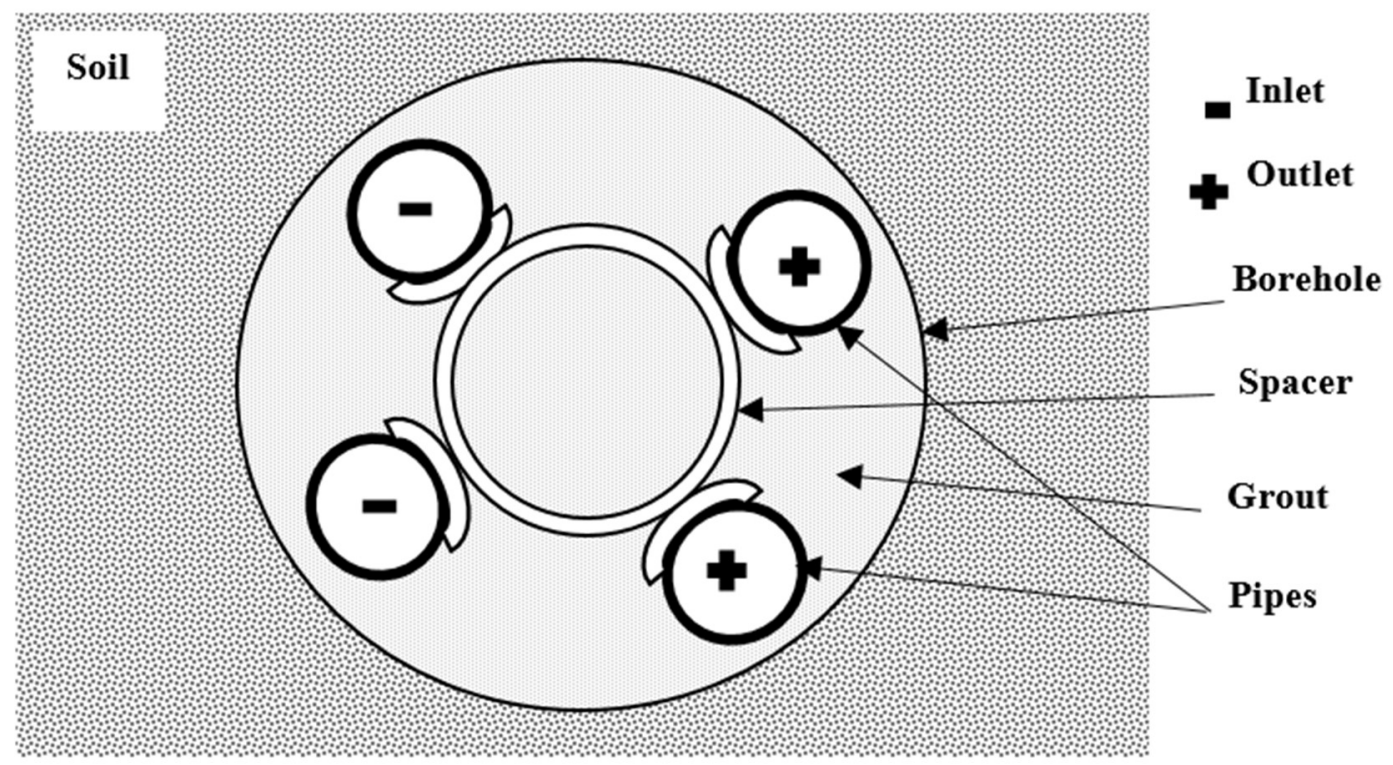

Figure 6. Cross section of double U-tube pipe with spacer to keep space constant.

Laboratory thermal response tests were conducted to evaluate the influence of groundwater flow on the heat transfer in the borehole ground heat exchangers. The effective thermal conductivity increased with an increase of the groundwater velocity [16].

It is a common practice in Scandinavia to use groundwater as grout between the U-tube and the borehole wall because the borehole is cased at the bottom to solid bedrock. The thermal resistance of groundwater borehole is lower compared to grouted boreholes because the heat transfer is enhanced by buoyancy-driven natural convection. A number of thermal response tests are conducted with different heat flow rates to identify the effect of convective heat flow in groundwater (as grout) on the heat transfer in ground heat exchangers constructed in solid/fractured bedrock. In the borehole heat exchanger constructed in solid bedrock, the convective flow in groundwater affected the borehole thermal resistance. The borehole thermal resistance decreased when the heat injection rate increased. In the fractured bedrock, the heat injection rate influenced the bedrock thermal conductivity. The thermal conductivity of the fractured bedrock increased with the increase of heat injection rate [17].

Six vertical ground heat exchangers were constructed in the field with different construction parameters to estimate the thermal efficiency of the GHEs. The three different construction parameters considered were: (1) grout materials (cement and bentonite), (2) pipe configurations (U-loop and new 3 pipe-type, as shown in Figure 7), and (3) additives (silica sand and graphite). It was found that the cement grout has a higher heat transfer efficiency than the bentonite grout. In addition, the thermal efficiency of 3 pipe-type configuration with the cement silica sand grout was higher than that of U-loop with the same grout [18].

Nine thermal response tests were carried out (TRTs) at the Chalmers University of Technology in Sweden to determine the ground properties inside and in the vicinity of the nine boreholes during 
heat injection. Groundwater filled the space between the borehole (depth $80 \mathrm{~m}$ ) and U-tube. The same heat injection and turbulent water flow rate were used for the nine boreholes, and the minimum test duration was about $48 \mathrm{~h}$. The mean value of the thermal conductivity of the nine boreholes was $3.01 \mathrm{~W} / \mathrm{m} \cdot \mathrm{K}$ with $\pm 7 \%$ variation. The estimated borehole thermal resistances for nine boreholes were within a range of $0.062 \pm 0.012 \mathrm{~m} \cdot \mathrm{K} / \mathrm{W}$ [19].

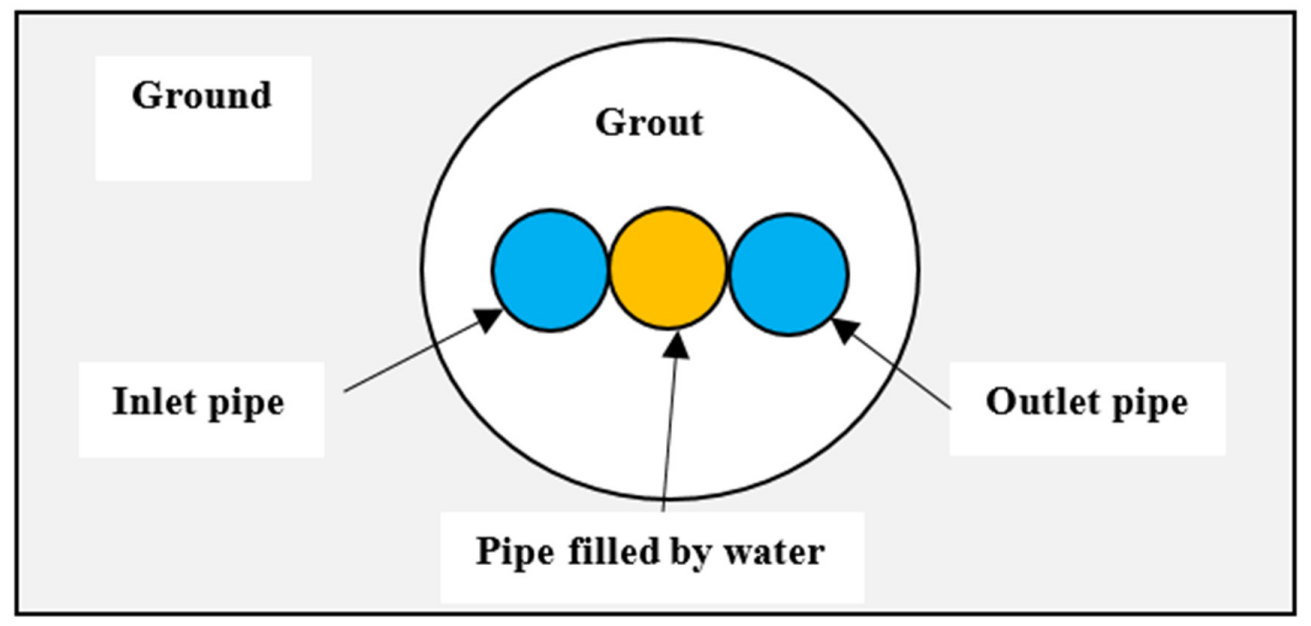

Figure 7. Cross section of new 3 pipe-type.

New grout mixtures which were produced from industrial waste such as pulverized fuel ash (PFA) were proposed to improve the heat transfer characteristics of the borehole ground heat exchangers. The PFA was mixed with different grout materials such as fine sand, coarse sand, ground glass, and fluorspar. It was found that the heat transfer characteristics of the borehole ground heat exchangers improved when PFA mixed with fluorspar/coarse sand was used as grout material [20].

Laboratory studies were performed for a concentric ground heat exchanger to compare two different grouts (phase change materials (PCMs) and sand soil) to improve the thermal performance of ground heat exchangers. The results showed that the soil temperature oscillates less with PCMs grout than with sand soil grout [21].

A small-scale borehole heat exchanger (BHE) was inserted in the insulating sandbox (length: $1 \mathrm{~m}$; depth: $1 \mathrm{~m}$, and width: $1 \mathrm{~m}$ ), and two parallel pipes were inserted in $1 \mathrm{~m}$ depth of the BHE. The main objective was to estimate the effects of three different grouts (silica sand-based, bentonite-based, and homemade admixture containing natural graphite) on the thermal resistance of the borehole heat exchangers. The results indicated that the homemade admixture with $5 \%$ natural graphite was the best option as grout in the borehole heat exchanger [22].

A numerical model was suggested for the BHE in the five-layered subsurface. The influence of groundwater flow was taken into account to minimize the total borehole length. Numerical analysis was used to estimate the performance of heat transfer characteristics of the BHEs with and without groundwater flow. The results indicated that the convection flow in groundwater leads to increased heat transfer between BHE and the ground by 55\% [23].

Field studies were performed to estimate the influence of two different grout materials (cement-grout and gravel-backfill) on the borehole thermal resistance of BHEs. The borehole thermal resistance of the BHE with gravel-backfill $(0.141 \mathrm{~m} \cdot \mathrm{K} / \mathrm{W})$ was lower than the same with cement-grout $(0.155 \mathrm{~m} \cdot \mathrm{K} / \mathrm{W})$. In addition, use of gravel-backfill reduces the installation cost and time compared to cement-grouted. The space between the U-tube and the borehole took $2 \mathrm{~h}$ to fill with gravel-backfill, while it needed three days to fill with cement-grout [24].

Field thermal response tests were performed at two different locations to study the effects of the groundwater level on the effective ground thermal conductivity and heat transfer rate of the borehole 
heat exchangers. It was reported that the effective ground thermal conductivity and heat transfer rate of the borehole heat exchangers increased with an increase in the level of the groundwater [25].

Field studies were conducted to investigate the effects of different rock types (alluvial deposit, granite, and gneiss) and borehole depths (150 and $200 \mathrm{~m}$ ) on the effective ground thermal conductivity. The results indicated that the effective ground thermal conductivity increased by increasing the borehole depth. The results also showed that gneiss was the best option to increase the effective ground thermal conductivity, followed by alluvial deposit and granite [26].

\subsection{Influence of Different Pipe Configurations on the Thermal Performance of Ground Heat Exchangers}

A novel quasi-three-dimensional model was developed for GHEs to understand the heat transfer processes that occurs in GHEs during the heat injection and rejection. Analytical solutions were used to evaluate the thermal resistance for different configurations of single and double U-tube boreholes. The obtained results showed that the double U-tube borehole had 30-90\% lower thermal resistance than the single U-tube borehole [27].

A new configuration of coaxial borehole heat exchanger was suggested to improve the thermal performance of a borehole heat exchanger. The coaxial borehole heat exchanger comprises of pipe-in-pipe in which the outer pipe contacted directly with the surrounding bedrock. The goal of this study was to compare the thermal efficiency of a conventional U-tube borehole heat exchanger with a new coaxial borehole heat exchanger. The temperature of the fluid was measured at specific points by using fiber optic cables installed in the borehole. The heat transfer performance of coaxial heat exchanger was better than a common U-tube heat exchanger [28].

A novel coaxial borehole ground heat exchanger (pipe-in-pipe with external insulation around the central pipe) was suggested to improve the heat transfer rate. The numerical results indicated that the heat extracted from the ground by using coaxial borehole heat exchanger with insulation was $40 \%$ higher than the same without insulation [29].

Thermal response tests were conducted to evaluate the thermal performance of GHEs with three different pipe configurations in Oklahoma City. The three different pipe configurations were: (1) coaxial, (2) double U-tube, and (3) single U-tube. The results showed that the best option to reduce the thermal resistance of the borehole was the double U-tube heat exchanger, followed by a single U-tube heat exchanger and a coaxial heat exchanger [30].

Field experiment studies were undertaken to estimate the impact of different pipe configurations on the thermal borehole resistance of borehole heat exchangers (BHEs). In this study, the three different pipe configurations were: (1) coaxial (115 mm borehole diameter), (2) single U-tube (180 $\mathrm{mm}$ borehole diameter), and (3) double U-tube (180 $\mathrm{mm}$ borehole diameter), all with the same depth $(30 \mathrm{~m})$. The distance between each borehole was $5 \mathrm{~m}$, as shown in Figure 8 . The results showed the ground thermal conductivity for the coaxial BHE was $2.21 \mathrm{~W} / \mathrm{m} \cdot \mathrm{K}$, and the borehole thermal resistance was $0.344 \mathrm{~m} \cdot \mathrm{K} / \mathrm{W}$. The thermal resistance of the double U-tube was $0.162 \mathrm{~m} \cdot \mathrm{K} / \mathrm{W}$, which represented the best BHE performance, followed by the single U-tube type $(0.251 \mathrm{~m} \cdot \mathrm{K} / \mathrm{W})$, and coaxial type $(0.344 \mathrm{~m} \cdot \mathrm{K} / \mathrm{W})[31]$.

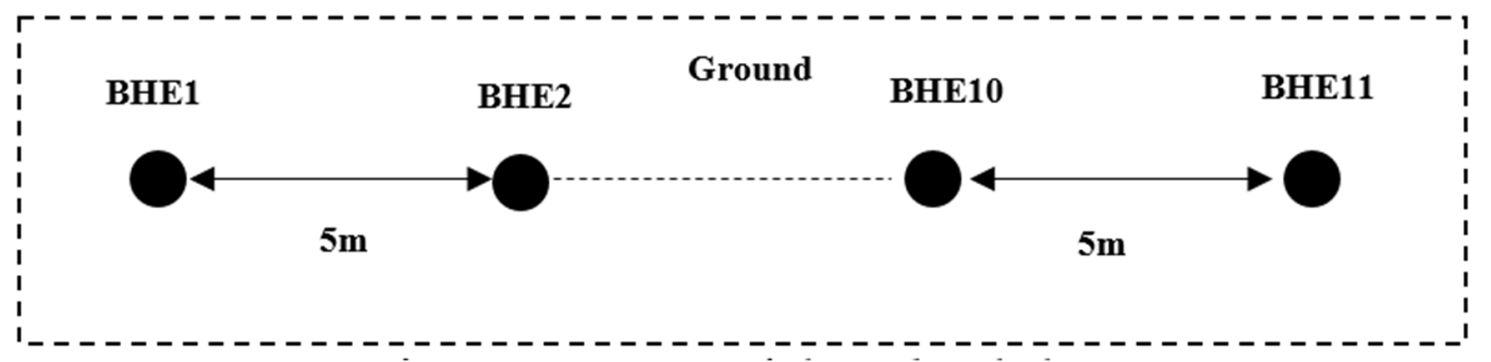

Figure 8. Top view of eleven boreholes. 
Field studies were conducted by using a new method (Distributed Thermal Response Test (DTRT)) to study the effects of different volumetric flow rates $(0.13,0.21,0.24 \mathrm{l} / \mathrm{s})$ and pipe configurations (U-tube, pipe-in-pipe, and multi-pipe) on the ground properties of BHEs. The local borehole resistances were 0.015 and $0.040 \mathrm{~K} \cdot \mathrm{m} / \mathrm{W}$ in pipe-in-pipe and multi-pipe BHEs, respectively, which were substantially lower than the same for single U-tube BHE. The results also showed the increased temperature difference between pipes due to the decline of the flow rates, which was followed by decreasing evaporation temperature in the heat pump [32].

Numerical studies were carried out to estimate the influence of two different parameters (volumetric flow rates and pipe configurations) on the heat extraction rate of GHEs. Three different pipe configurations were used for small diameter boreholes: (1) single U-tube, (2) double cross U-tube, and (3) double U-tube, and two different pipe configurations were used for larger diameter boreholes: (1) spiral, and (2) multiple U-tube. The results showed the thermal performance in GHEs improved by using turbulent flow rate and increasing the flow rate in pipes. The performance of the double U-tube in small diameter borehole had a range between $8 \%$ to $23 \%$ higher than double cross U-tube in the same small diameter borehole. There was little change in the performance of the spiral and multiple U-tubes in the larger diameter borehole when the pipe lengths inside the borehole were the same [33].

Experimental studies were conducted to investigate the performance of three different pipe configurations (single U-tube, double U-tube, and triple U-tubes) inserted in GHEs. The results showed the increasing number of U-tubes in the borehole led to an increase in the performance of the borehole. It was also reported that the performances of triple U-tube and double U-tube were $33 \%$ and $17 \%$ higher than the same for single U-tube. The drilling cost was also reduced up to $25 \%$ with triple U-tube in the borehole [34].

A numerical analysis (Computational Fluid Dynamics (CFD) code) was used to compare the thermal performance of U-tube and spiral-tube GHEs in both laminar and turbulent flow conditions. The thermal performance of the spiral-tube GHE was compared with the U-tube GHE. In the laminar flow, the performance of the spiral-tube increased by $62.7 \%$, and in the turbulent, it increased by $33.5 \%$ [35].

Numerical studies were carried out to estimate the internal thermal processes between pipes inside the boreholes and thermal performance of multiple-tube GHEs. In this study, four different ground heat exchangers: (1) single U-tube, (2) multi-tube, (3) three-tube, and (4) four-tube were used, as shown in Figure 9. The thermal performances of multi-tube, four-tube, and three-tube GHEs were compared with the single U-tube GHE. It increased by $20.1 \%$ for multi-tube, $13.6 \%$ for four-tube, and $9.1 \%$ for three-tube. It was reported that the thermal performance was influenced by the internal thermal processes between tubes in the boreholes. The heat exchange rate increased between the boreholes and the ground due to an increase in the number of inlet tubes in the borehole [36].

(1)

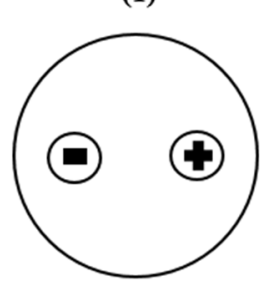

(2)

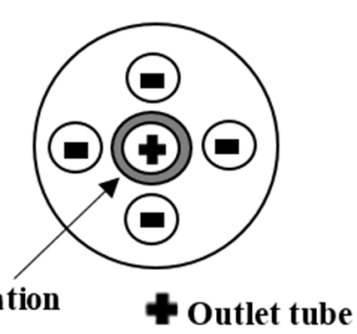

(3)

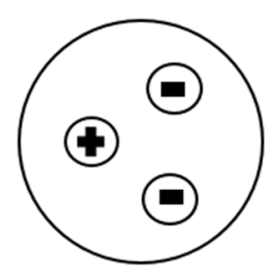

- Inlet tube

Figure 9. Cross sections of four ground heat exchangers (GHEs): (1) single U-tube, (2) multi-tube, (3) three-tube, and (4) four-tube.

Field studies were conducted to estimate the thermal resistance and the average circulating water temperature (ACWT) for three different pipe configurations: (1) new design which has three inlet pipes and one outlet (3I-type), (2) double U-tube, and (3) single U-tube, as shown in Figure 10. 
The experimental results indicated that the average circulating water temperatures for single U-tube and double U-tube were $3.7^{\circ} \mathrm{C}$ and $1^{\circ} \mathrm{C}$ higher than the same for 3I-type. The results also showed the best option to reduce the thermal resistance of the borehole was the 3I-type, followed by the double U-tube and the single U-tube [37].

\section{Large pipe diameter}

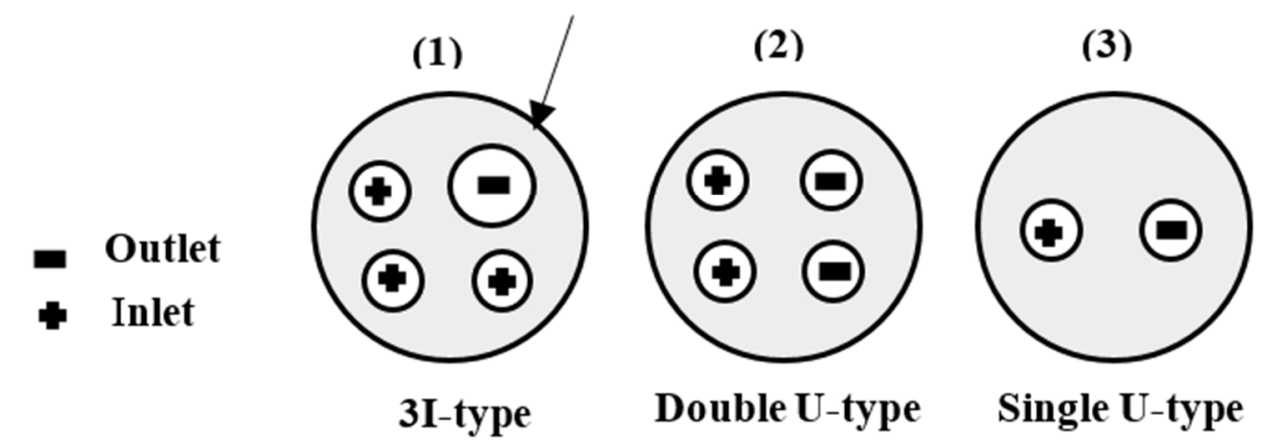

Figure 10. Cross section of the 3I-type, double U-tube, and single U-tube.

Experimental and numerical studies were conducted to estimate the thermal efficiency of two types of GHEs: coil-type and W-type energy piles. There were good agreements between numerical analysis outputs and experimental observations. Numerical analysis was utilized to predict the heat exchange rate in ground heat exchangers (coil-type and W-type energy piles) over a period of three months. The results indicated that the coil-type has higher heat exchange efficiency than the same for W-type but was found to be more expensive than the W-type [38].

An analytical design calculation suggested that the coaxial GHEs at a high flow rate have less borehole thermal resistance (below $0.05 \mathrm{~K} \cdot \mathrm{m} / \mathrm{W}$ ) than a single U-tube. On the other hand, the coaxial GHEs have higher borehole thermal resistance than double U-pipe GHEs [39].

Two field studies were conducted to evaluate the effects of two different pipe configurations (single U-tube and double U-tube) on thermal performance of the GHEs. The results indicated that the ground thermal conductivity values of the double U-tube and single U-tube were 3.17 and $3.03 \mathrm{~W} / \mathrm{m} \cdot \mathrm{K}$, respectively. The borehole thermal resistance values of the double U-tube and single U-tube were 0.081 and $0.13 \mathrm{~m} \cdot \mathrm{K} / \mathrm{W}$, respectively [40].

Experimental and numerical studies were carried out to estimate the thermal efficiency of four types of energy pile GHEs: double-U, triple-U, double-W, and spiral. The results showed that triple-U type was the best option for thermal efficiency. The results also showed that the highest economic performance was triple-U type, followed by double-U type, spiral type and double-W type [41].

Field studies were conducted to evaluate the effects of increased number of tubes and tube diameters, as shown in Figure 11, on the thermal performance of the GHEs. It was reported that more tubes and larger tube diameter in the borehole led to reduced grout space, followed by decreased water temperature entering into the heat pump [40].

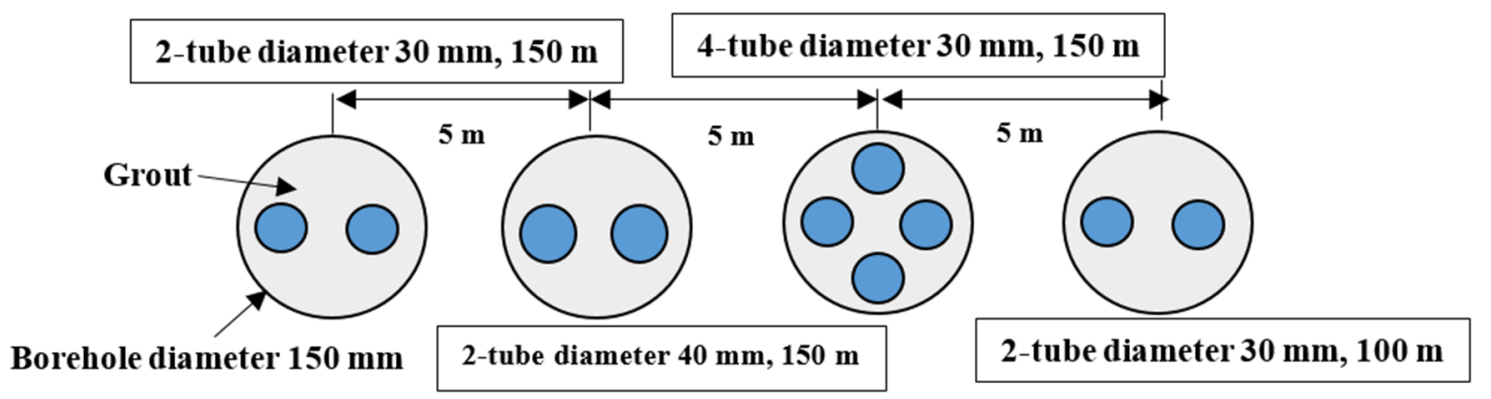

Figure 11. Cross section of ground heat exchangers. 
Small-scale laboratory studies were performed to estimate the influences of different pipe configurations: single and double U-tubes (with or without spacers), as shown in Figure 12, and helical-shaped pipe on the efficiency of GHEs. The best heat transfer rate was found in the helical pipe GHE, compared to both single and double U-tube (with or without spacers) GHEs. It was also reported that the thermal efficiency of single U-tube and double U-tube GHEs with spacers improved by $30 \%$, compared to the same without spacers [42].
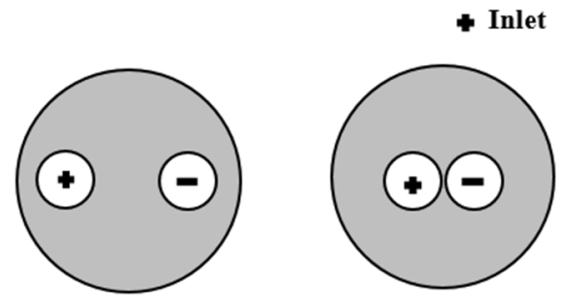

Single U-tube without spacers

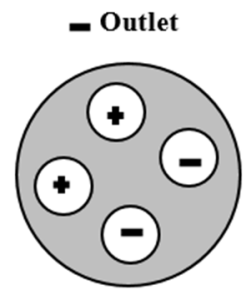

Double U-tube with spacers

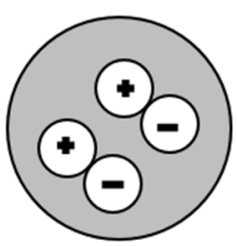

Double U-tube without spacers

Single U-tube with spacers

Figure 12. The position of the single and double U-tube with and without spaces.

\subsection{Effects of Borehole Depths and Diameters on the Thermal Performance of Ground Heat Exchangers}

First field studies were carried out, supported by numerical analysis, at a depth of $22 \mathrm{~m}$ in Latin America to estimate the borehole thermal resistance and the thermal conductivity of the ground. Thermal conductivity of the ground was calculated by using line source theory [6], which was lower compared to the same obtained from numerical analysis [43].

First field thermal response test was conducted to evaluate the thermal performance of U-tube borehole heat exchangers in Cyprus. Line source model was used to evaluate the thermal conductivity of the ground layers composed of clay, silt and sand, and the borehole thermal resistance. Boreholes were of $50 \mathrm{~m}$ depth. The thermal conductivity for the ground was $1.605 \mathrm{~W} / \mathrm{m} \cdot \mathrm{K}$ and the borehole thermal resistance was $0.257 \mathrm{~m} \cdot \mathrm{K} / \mathrm{W}$ [44].

The first thermal response test in Saudi Arabia was carried out to calculate the ground thermal properties such as the thermal conductivity, the thermal diffusivity, and the borehole thermal resistance for borehole heat exchangers with single U-tube. The borehole depth was $100 \mathrm{~m}$ and bentonite-sand mixture filled the spaces between the borehole and the U-tube. The mean undisturbed ground temperature was $32.6{ }^{\circ} \mathrm{C}$ before the thermal response test started. The thermal characteristics derived from experimental data using line source theory were: thermal conductivity $2.154 \mathrm{~W} / \mathrm{m} \cdot \mathrm{K}$, thermal diffusivity $6.252 \times 10^{-6} \mathrm{~m}^{2} / \mathrm{s}$, and thermal resistance of the borehole wall $0.315 \mathrm{~m} \cdot \mathrm{K} / \mathrm{W}$ [45].

Three thermal response tests (TRTs) were conducted with different borehole depths $(30 \mathrm{~m}, 60 \mathrm{~m}$ and $90 \mathrm{~m}$ ), all with a $150 \mathrm{~mm}$ borehole diameter in the garden of a village house in Elazing, Turkey to study the temperature distributions in boreholes of a conventional U-tube borehole heat exchanger. The results from the cooling and heating experiments showed that the $90 \mathrm{~m}$ depth borehole heat exchanger had a better performance than those with the depths of $60 \mathrm{~m}$ and $30 \mathrm{~m}$. The coefficient of performance (COP) of a heat pump is the ratio of energy output to the energy input. However, considering the borehole digging cost, the optimum depth was found to be $60 \mathrm{~m}$ with $\mathrm{COP}=3.0$ [46].

Laboratory experiment in a horizontal sandbox (length: $18 \mathrm{~m}$; depth: $1.8 \mathrm{~m}$, and width: $1.8 \mathrm{~m}$ ) with a single U-tube was conducted with GHE to estimate the ground thermal properties. A large number of thermocouples were placed at specific locations in the sandbox to understand the heat transfer process in and around the GHE. Researchers utilized the temperature data collected at the borehole wall to determine the borehole thermal resistance. Temperature data collected during the test within the soil were used to estimate the soil thermal conductivity. The values of borehole thermal resistance and soil thermal conductivity were used to verify the heat transfer in the borehole ground heat exchanger [47]. 
A novel approach (Distributed Thermal Response Test) was developed to determine the thermal conductivity of the ground and thermal resistance of the BHE at different depths. Figure 13 shows the cross section of coaxial borehole heat exchanger. This study showed that the borehole thermal resistance (local and global) of the coaxial heat exchanger is lower than the same for a single U-tube borehole heat exchanger [48].

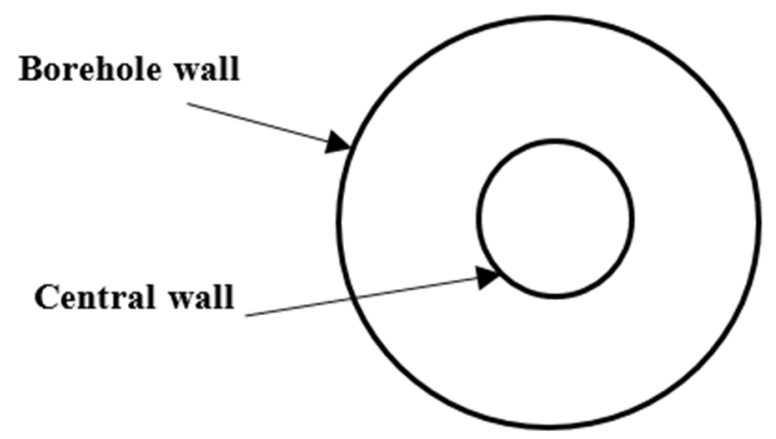

Figure 13. Cross section of coaxial borehole heat exchanger.

Field studies were performed to investigate the effects of different borehole diameters (121 mm, $165 \mathrm{~mm}$, and $180 \mathrm{~mm}$ ) (see Figure 14) on the thermal efficiency of BHEs. The results showed that the larger diameter led to an increase in the thermal exchange rate. In the seasonal cooling period, the amount of thermal exchange in the 180 and $165 \mathrm{~mm}$ borehole diameters were $7.1 \%$ and $3.2 \%$ higher than the same for $121 \mathrm{~mm}$ borehole diameter [49].
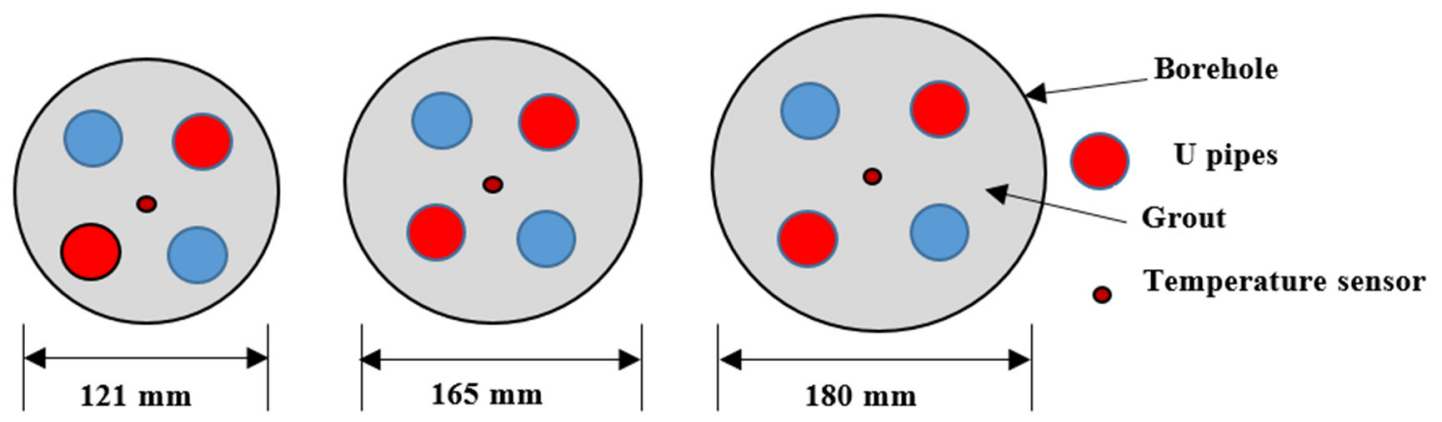

Figure 14. Cross section of different borehole diameters.

An experimental study was conducted with a single borehole (length: $400 \mathrm{~mm}$ ) inserted at the center from the top of the sand tank (length: $1.35 \mathrm{~m}$, and diameter $1.4 \mathrm{~m}$ ) to measure the borehole wall temperature at various depths and different times $(1,6,12,24,168 \mathrm{~h})$ during the thermal response test. The results indicated that the temperature at borehole wall increased with the duration of the thermal response test [50].

Field studies were performed to estimate the ground thermal properties at the Technical University of Sofia, Bulgaria. A mobile system was built and used for conducting the thermal response tests. In this study, temperature data were collected during two thermal response tests for single U-tube borehole ground heat exchangers in 2011 and 2012 and were compared. In 2011, the ground thermal conductivity was $1.58 \mathrm{~W} / \mathrm{m} \cdot \mathrm{K}$ and the borehole thermal resistance was $0.187 \mathrm{~m} \cdot \mathrm{K} / \mathrm{W}$, while in 2012, the ground thermal conductivity was $1.65 \mathrm{~W} / \mathrm{m} \cdot \mathrm{K}$ and the borehole thermal resistance was $0.179 \mathrm{~m} \cdot \mathrm{K} / \mathrm{W}$ [51].

\subsection{Miscellaneous Issues Related to Performance of Ground Heat Exchangers}

Numerical studies were carried out to predict transient ground heat transfer behavior of the vertical U-tube with different pipe diameters, shank spacing, and borehole sizes. Numerical observations were compared with known analytical case solutions [52]. 
A three-dimensional unstructured finite volume model for conventional single U-tube was developed. In this study, Delaunay triangulation method was utilized to mesh the cross section of the borehole field, including inside and around the borehole. In order to calculate the effect of the temperature change with the depth, the ground was divided into many layers. The inlet fluid temperature of the borehole was used as a boundary condition, and the inner and outer surfaces of the two legs of the U-tube were considered as the conjugated interfaces in the area. Therefore, the conjugate heat transfer processes in and around the pipes could be calculated. There was a good agreement for the outlet water temperature both when measured during the experiment and predicted by the numerical model [53].

A three dimensional numerical computational-fluid-dynamics model was implemented to predict the complex heat transfer process with approximately 3.5\% error. Statistical analyses were conducted to show how different design parameters could simultaneously impact the response variables [54].

Rest or recovery period needed was measured for the borehole after the thermal response test to return to the initial ground temperature prior to the test. Thermal response tests were carried out by using many heat injections of different rates and time durations. The recovery time of the initial ground temperature depends on the time and the rate of heat injection throughout the test. The initial ground temperature returned to within $0.3 \mathrm{~K}$ after 10 days when the thermal response test was conducted for $48 \mathrm{~h}$ and the rate of heat injection was $67 \mathrm{~W} / \mathrm{m}$. There was also a close agreement between the temperatures obtained from the mathematical model and experiment. It was noted that the recovery time increases with the duration of test and rate of the heat injection [55].

It is reported that a number of residential-size GSHPs were installed in cold climates of Alaska to estimate the performance of GSHPs. The results showed that the ground source heat pumps were effective in cold climates, and the COP was between 2.0 and 3.5 [56].

A residential-size GSHP was installed in Fairbanks, Alaska to study the impacts of the heat extraction over a period of three months on the ground thermal properties and any decline in heat pump system efficiency. The results showed that the surrounding soil temperature was higher than the soil temperature around the ground heat exchanger. The results also indicated that the COP of the circulating pumps and the heat pump was 3.3 [57].

Four field tests on two boreholes (depth $40 \mathrm{~m}$ ) were performed to evaluate the ground properties of double U-tube ground heat exchangers used for thermal energy storage in Melbourne, Australia. As the heat injection rate was not constant during the thermal response test, the results were compared by three different methods: (1) conventional slope determination, (2) geothermal properties measurement (GPM) model, and (3) two parameter curve fitting. There was a good agreement between the geothermal properties measurement (GPM) model and two parameter curve fittings. The values of the ground properties were variable while using the slope determination method because the heat injection was not constant during the thermal response test (TRT). The results also showed the difference between the conventional slope determination method and the other two methods, ranging from $2 \%$ to $37 \%$ [58].

A small experimental apparatus for a single U-tube ground heat exchanger was established in the laboratory to study transient heat transfer. At the same time, results from an axisymmetric numerical model of the ground surrounding the borehole were compared with the experimental results. There was an agreement between the experimental and numerical results which indicates the accuracy of the data collected from the experimental setup [59].

First field thermal response test was conducted to estimate the soil thermal response in Guayaquil, Ecuador. It was reported that the soil temperature was between 27 and $29^{\circ} \mathrm{C}$. The results also showed the thermal conductivity of the soil was $1.13 \mathrm{~W} / \mathrm{m} . \mathrm{K}$ and the borehole thermal resistance was $0.33 \mathrm{~m} \cdot \mathrm{K} / \mathrm{W}[60]$

A field test was carried out to estimate the distribution of undisturbed ground temperature during the period of heat injection in underground thermal energy storage system established in Golden, Colorado, USA. The system comprised of five boreholes with a depth of $9 \mathrm{~m}$, and the center to center distance between these boreholes was $2.5 \mathrm{~m}$. It was indicated that during a period of 75 days, a constant 
heat of $20 \mathrm{~W} / \mathrm{m}$ was injected into the ground. The undisturbed ground temperature was increased by $7^{\circ} \mathrm{C}$. Four months later, it was noticed that the heat storage decreased by $60 \%$ [61].

A novel transient quasi-3D entire time scale line source model was developed, which studied transient borehole thermal resistance and examines the heat flux profile along the two legs of the Utube as a variable. The results were compared with experimental sandbox and maximum relative error was found to be less than $5 \%$ [62].

The effect of many variables were analyzed on the GSHPs currently installed in 24 buildings in cold climate zones of the United States. The factors included in the study were: (1) system performance, (2) potential energy savings, (3) cost of system, (4) operational difficulties, (5) purpose of using geothermal system, and (6) owner satisfaction to date. The results showed that $75 \%$ of building owners were highly satisfied with the use of GSHP systems, including noise level, cost, and comfort. Approximately $85 \%$ of homeowners encouraged other people to use this technology, and about $71 \%$ of GSHP systems did not have issues during their operation. Furthermore, the study showed that the overall performance of the real GHP systems used in cold climate regions was $6.1 \%$ lower in energy consumption and about $7.2 \%$ lower in cost savings than the national energy use and mean energy costs in similar buildings in the United States [63].

A comprehensive list of all literatures discussed in this section is shown in Table 1.

Table 1. Summary of the papers discussed.

\begin{tabular}{|c|c|c|}
\hline Source & Description & Conclusion/s or Observation/s \\
\hline Remund C. P (1999) [12] & $\begin{array}{l}\text { Investigated the impacts of grout on the } \\
\text { effective borehole thermal resistance. }\end{array}$ & $\begin{array}{l}\text { Increased thermal conductivity of grout } \\
\text { reduced the borehole thermal resistance. }\end{array}$ \\
\hline Allan and Kavanaugh (1999) [13] & $\begin{array}{l}\text { Studied how cement-sand, bentonites, } \\
\text { and neat cements grout would affect the } \\
\text { borehole length. }\end{array}$ & $\begin{array}{l}\text { Borehole length decreased cement-sand } \\
\text { was used as grout compared to } \\
\text { bentonites and neat cements. }\end{array}$ \\
\hline Abu-Hamdeh et al. (2001) [14] & $\begin{array}{l}\text { Examined the effects of bulk density } \\
\text { and moisture content on the thermal } \\
\text { conductivity of some Jordanian soils. }\end{array}$ & $\begin{array}{l}\text { Soil thermal conductivity increased with } \\
\text { the increase of soil density and } \\
\text { moisture content. }\end{array}$ \\
\hline Pahud and Matthey (2001) [15] & $\begin{array}{l}\text { Estimated the effects of bentonite, } 50 \% \\
\text { sand and bentonite, and quartz sand, } \\
\text { with and without spacers. }\end{array}$ & $\begin{array}{l}\text { The quartz sand and spacers was the } \\
\text { best option to increase the efficiency. } \\
\text { The borehole thermal resistances with } \\
\text { spacers was less than the same } \\
\text { without spacers. }\end{array}$ \\
\hline Katsura et al. (2006) [16] & $\begin{array}{l}\text { Evaluated the influence of ground water } \\
\text { flow on the heat transfer in the GHEs. }\end{array}$ & $\begin{array}{l}\text { The effective thermal conductivity } \\
\text { increased with an increase in the ground } \\
\text { water velocity. }\end{array}$ \\
\hline $\begin{array}{l}\text { Gustafsson and Westerlund } \\
\text { (2010) [17] }\end{array}$ & $\begin{array}{l}\text { Considered the effects of the convective } \\
\text { heat flow on the heat transfer in } \\
\text { the GHEs. }\end{array}$ & $\begin{array}{l}\text { In the solid bedrock, the borehole } \\
\text { thermal resistance decreased when the } \\
\text { convective heat flow increased. The } \\
\text { heat flow through fractured bedrock } \\
\text { increased with increased convective } \\
\text { heat flow. }\end{array}$ \\
\hline Lee et al. (2011) [18] & $\begin{array}{l}\text { Estimated the thermal efficiency of } \\
\text { GHEs with U-loop and 3-pipe. }\end{array}$ & $\begin{array}{l}\text { The thermal efficiency of 3-pipe } \\
\text { configuration was higher than U-loop. }\end{array}$ \\
\hline Alrtimi et al. (2013) [20] & $\begin{array}{l}\text { Proposed new grout mixtures which } \\
\text { were produced from industrial waste } \\
\text { such as pulverized fuel ash (PFA) to } \\
\text { improve the heat transfer characteristics } \\
\text { of the borehole heat exchangers. }\end{array}$ & $\begin{array}{l}\text { The thermal conductivities of fluorspar } \\
\text { and coarse sand, all with } 20 \% \text { of PFA } \\
\text { were the highest thermal conductivities } \\
\text { compared to other grouts. }\end{array}$ \\
\hline Lei and Dai (2013) [21] & $\begin{array}{l}\text { Compared phase change materials and } \\
\text { sand-soil. }\end{array}$ & $\begin{array}{l}\text { The soil temperature oscillates less with } \\
\text { PCMs grouts than with sand-soil grout. }\end{array}$ \\
\hline Erol and François (2014) [22] & $\begin{array}{l}\text { Examined the silica sand-based, the } \\
\text { bentonite-based, and homemade } \\
\text { admixture as grout in the GHE. }\end{array}$ & $\begin{array}{l}\text { The homemade admixture with } 5 \% \\
\text { natural graphite was the best option as } \\
\text { grout in the GHE. }\end{array}$ \\
\hline
\end{tabular}


Table 1. Cont.

\begin{tabular}{|c|c|c|}
\hline Source & Description & Conclusion/s or Observation/s \\
\hline Erol and François (2014) [22] & $\begin{array}{l}\text { Examined the silica sand-based, the } \\
\text { bentonite-based, and homemade } \\
\text { admixture as grout in the GHE. }\end{array}$ & $\begin{array}{l}\text { The homemade admixture with } 5 \% \\
\text { natural graphite was the best option as } \\
\text { grout in the GHE. }\end{array}$ \\
\hline Luo et al. (2015) [23] & $\begin{array}{l}\text { Estimated the performance of heat } \\
\text { transfer characteristic of the GHEs with } \\
\text { and without groundwater flow. }\end{array}$ & $\begin{array}{l}\text { The convection flow in groundwater led } \\
\text { to increased heat transfer between GHE } \\
\text { and the ground. }\end{array}$ \\
\hline Choi and Ooka (2016) [24] & $\begin{array}{l}\text { Studied the influences of cement-grout } \\
\text { and gravel-backfill on the borehole } \\
\text { thermal resistance of GHEs. }\end{array}$ & $\begin{array}{l}\text { The borehole thermal resistance of the } \\
\text { GHE with gravel-backfill was lower } \\
\text { than the same with cement-grout. }\end{array}$ \\
\hline Luo et al. (2018) [25] & $\begin{array}{l}\text { Examined the effects of the groundwater } \\
\text { level on effective ground thermal } \\
\text { conductivity and heat transfer rate } \\
\text { of GHEs. }\end{array}$ & $\begin{array}{l}\text { The effective ground thermal } \\
\text { conductivity and heat transfer rate of } \\
\text { borehole heat exchangers increased with } \\
\text { increasing level of the groundwater. }\end{array}$ \\
\hline Lee C (2019) [26] & $\begin{array}{l}\text { Studied the effects of different rock } \\
\text { types (alluvial deposit, granite, and } \\
\text { gneiss) and borehole depths ( } 150 \mathrm{~m} \text { and } \\
200 \mathrm{~m} \text { ) on the effective ground } \\
\text { thermal conductivity. }\end{array}$ & $\begin{array}{l}\text { The effective ground thermal } \\
\text { conductivity increased by increasing the } \\
\text { borehole depth. The gneiss had the } \\
\text { maximum effective ground } \\
\text { thermal conductivity. }\end{array}$ \\
\hline Zang et al. (2003) [27] & $\begin{array}{l}\text { Developed a novel } \\
\text { quasi-three-dimensional model to } \\
\text { estimate ground properties. }\end{array}$ & $\begin{array}{l}\text { The double U-tube has a thermal } \\
\text { resistance lower than the single U-tube. }\end{array}$ \\
\hline Acuña and Palm (2010) [28] & $\begin{array}{l}\text { Suggested a new configuration to } \\
\text { improve the thermal performance } \\
\text { of GHE. }\end{array}$ & $\begin{array}{l}\text { The performance of the heat transfer in } \\
\text { a new configuration (pipe in pipe) is } \\
\text { better than the U-tube. }\end{array}$ \\
\hline Guillaume F (2011) [29] & $\begin{array}{l}\text { Introduced a new approach of coaxial } \\
\text { GHE with external insulation around } \\
\text { the central pipe. }\end{array}$ & $\begin{array}{l}\text { The heat extracted from the ground by } \\
\text { using coaxial GHE with insulation was } \\
\text { higher than the same for } \\
\text { without insulation. }\end{array}$ \\
\hline Beier and Ewbank (2012) [30] & $\begin{array}{l}\text { Performed TRTs for GHEs with different } \\
\text { pipe configurations (coaxial, double } \\
\text { U-tube, and single U-tube). }\end{array}$ & $\begin{array}{l}\text { The thermal resistance of borehole was } \\
\text { the least when pipe configuration was } \\
\text { double U-tube. }\end{array}$ \\
\hline Desmedt et al. (2012) [31] & $\begin{array}{l}\text { Estimated the impact of coaxial, single } \\
\text { U-tube, and double U-tube on the } \\
\text { borehole thermal resistance of GHEs. }\end{array}$ & $\begin{array}{l}\text { The thermal resistance of the double } \\
\text { U-tube was lower than single U-tube } \\
\text { type, and coaxial type. }\end{array}$ \\
\hline Acuña J (2013) [32] & $\begin{array}{l}\text { Used a new method to study the effects } \\
\text { of different volumetric flow rates on the } \\
\text { performance of GHEs. }\end{array}$ & $\begin{array}{l}\text { The temperature difference between } \\
\text { pipes increased due to the decline of the } \\
\text { flow rates. }\end{array}$ \\
\hline Bidarmaghz et al. (2013) [33] & $\begin{array}{l}\text { Estimated the effects of the fluid flow } \\
\text { rate on the thermal performance of } \\
\text { GHEs. }\end{array}$ & $\begin{array}{l}\text { The thermal performance in GHEs } \\
\text { improved by using turbulent flow and } \\
\text { increasing the flow rate in pipes. }\end{array}$ \\
\hline Dincer et al. (2014) [34] & $\begin{array}{l}\text { Estimate the performance of single } \\
\text { U-tube, double U-tube, and triple } \\
\text { U-tubes of GHEs. }\end{array}$ & $\begin{array}{l}\text { The performance of triple U-tube was } \\
\text { higher than the double U-tube and } \\
\text { single U-tube. }\end{array}$ \\
\hline Haddada and Miyara (2014a) [35] & $\begin{array}{l}\text { Compared the performance of U-tube } \\
\text { and spiral-tube GHEs in both laminar } \\
\text { and turbulent flow conditions. }\end{array}$ & $\begin{array}{l}\text { In the laminar flow, the performance of } \\
\text { the spiral-tube increased by } 62.7 \% \text {, and } \\
\text { in the turbulent, it increased by } 33.5 \% \text {, } \\
\text { while compared with the single U-tube. }\end{array}$ \\
\hline Haddada and Miyara (2014b) [36] & $\begin{array}{l}\text { Estimated the performance of different } \\
\text { pipe configurations in GHEs. }\end{array}$ & $\begin{array}{l}\text { The heat exchange rate increased } \\
\text { between the boreholes and the ground } \\
\text { due to increased number of inlet tubes } \\
\text { in borehole. }\end{array}$ \\
\hline Liu et al. (2015) [37] & $\begin{array}{l}\text { Compared the influence of single } \\
\text { U-tube, double U-tube, and a new } \\
\text { design which has three inlet pipes and } \\
\text { one outlet (3Itype) on the borehole } \\
\text { thermal resistance. }\end{array}$ & $\begin{array}{l}\text { The borehole thermal resistance of the } \\
\text { 3Itype was lower than the double } \\
\text { U-tube and the single U-tube. }\end{array}$ \\
\hline
\end{tabular}


Table 1. Cont.

\begin{tabular}{|c|c|c|}
\hline Source & Description & Conclusion/s or Observation/s \\
\hline Yoon et al. (2015) [38] & $\begin{array}{l}\text { Estimated the thermal efficiency of two } \\
\text { types GHEs: coil-type and W-type. }\end{array}$ & $\begin{array}{l}\text { Coil-type had a higher heat exchange } \\
\text { efficiency than the same for } \mathrm{W} \text {-type. }\end{array}$ \\
\hline Raymond et al. (2015) [39] & $\begin{array}{l}\text { Preformed analytical models for two } \\
\text { coaxial pipe configurations with } \\
\text { different borehole diameters to reduce } \\
\text { the depth of the borehole. }\end{array}$ & $\begin{array}{l}\text { The borehole thermal resistance of the } \\
\text { coaxial GHEs decreased due to an } \\
\text { increase in the thermal conductivity of } \\
\text { the outer pipe. }\end{array}$ \\
\hline Chang and Kim (2016) [40] & $\begin{array}{l}\text { Evaluated the effects of increasing } \\
\text { number of tubes and tube diameters on } \\
\text { the performance of GHEs. }\end{array}$ & $\begin{array}{l}\text { Increasing number of tubes and using } \\
\text { large tube diameter in the borehole } \\
\text { leads to increased heat transfer in GHEs. }\end{array}$ \\
\hline Luo et al. (2016) [41] & $\begin{array}{l}\text { Compared the thermal efficiency of four } \\
\text { types GHEs: double-U, triple-U, } \\
\text { double-W, and spiral. }\end{array}$ & Tripe-U type was the best option. \\
\hline Blázquez et al. (2017) [42] & $\begin{array}{l}\text { Studied the impact of single and double } \\
\text { U-tube (with or without spacers), and } \\
\text { spiral pipes on the efficiency of GHEs. }\end{array}$ & $\begin{array}{l}\text { The performance of the U-tube VGHEs } \\
\text { with spacers was superior to the same } \\
\text { without spacers. }\end{array}$ \\
\hline Busso et al. (2003) [43] & $\begin{array}{l}\text { Conducted the first thermal response } \\
\text { test in Latin America to evaluate } \\
\text { ground properties. }\end{array}$ & $\begin{array}{l}\text { There were agreements between the } \\
\text { experimental results and the } \\
\text { numerical results. }\end{array}$ \\
\hline Florides and Kalogirou (2008) [44] & $\begin{array}{l}\text { Conducted the first thermal response } \\
\text { test in Cyprus to evaluate } \\
\text { ground properties. }\end{array}$ & $\begin{array}{l}\text { Thermal conductivity for the ground } \\
\text { was found to be } 1.605 \mathrm{~W} / \mathrm{m} \cdot \mathrm{K} \text { and } \\
\text { borehole thermal resistance was } \\
0.257 \mathrm{~m} \cdot \mathrm{K} / \mathrm{W} \text {. }\end{array}$ \\
\hline Sharqawy et al. (2009) [45] & $\begin{array}{l}\text { Conducted the first field study in Saudi } \\
\text { Arabia to calculate the ground } \\
\text { thermal properties. }\end{array}$ & $\begin{array}{l}\text { The mean undisturbed ground } \\
\text { temperature was } 32.6^{\circ} \mathrm{C} \text {. }\end{array}$ \\
\hline Esen and Inalli (2009) [46] & $\begin{array}{l}\text { Compared the thermal performance of } \\
\text { the single U-tube GHEs with } \\
\text { different depths. }\end{array}$ & $\begin{array}{l}\text { The thermal performance increased } \\
\text { with increased depths. }\end{array}$ \\
\hline Beier et al. (2011) [47] & $\begin{array}{l}\text { Designed a large laboratory sand tank } \\
\text { to verify the heat transfer in and around } \\
\text { the GHE. }\end{array}$ & $\begin{array}{l}\text { Thermal response tests results were } \\
\text { compared with several borehole models. }\end{array}$ \\
\hline Acuña and Palm (2013) [48] & $\begin{array}{l}\text { Developed a novel approach to } \\
\text { determine the ground properties of the } \\
\text { GHE at different depths. }\end{array}$ & $\begin{array}{l}\text { The borehole thermal resistance of the } \\
\text { coaxial pipe was lower than the same } \\
\text { for single U-tube. }\end{array}$ \\
\hline Luo et al. (2013) [49] & $\begin{array}{l}\text { Preformed field studies to investigate } \\
\text { the effects of different borehole } \\
\text { diameters on the thermal efficiency } \\
\text { of GHEs. }\end{array}$ & $\begin{array}{l}\text { The results showed that the larger } \\
\text { diameter leads to an increase in the heat } \\
\text { transfer rate. }\end{array}$ \\
\hline Cimmino and Bernier (2015) [50] & $\begin{array}{l}\text { Conducted laboratory study to measure } \\
\text { the borehole wall temperature during } \\
\text { the thermal response test and reach } \\
\text { steady state. }\end{array}$ & $\begin{array}{l}\text { The temperature at borehole wall } \\
\text { increased with increased duration of the } \\
\text { thermal response test. }\end{array}$ \\
\hline Georgiev et al. (2016) [51] & $\begin{array}{l}\text { Compared temperature data collected } \\
\text { during two thermal response tests in the } \\
\text { same area and at different times. }\end{array}$ & $\begin{array}{l}\text { Very small difference between } \\
\text { temperature data collected during } 2001 \\
\text { and } 2012 \text {. }\end{array}$ \\
\hline Yavuzturk et al. (1999) [52] & $\begin{array}{l}\text { Developed numerical model to } \\
\text { determine conduction heat transfer in } \\
\text { and vicinity of single U-tube ground } \\
\text { heat exchanger. }\end{array}$ & $\begin{array}{l}\text { Very small difference between the } \\
\text { numerical and analytical results. }\end{array}$ \\
\hline Li and Zheng (2009) [53] & $\begin{array}{l}\text { Developed a 3D numerical model to } \\
\text { predict the outlet water temperature for } \\
\text { single U- tube GHE. }\end{array}$ & $\begin{array}{l}\text { The experimental and numerical models } \\
\text { result showed close agreement for the } \\
\text { outlet water temperature. }\end{array}$ \\
\hline Khalajzadeh et al. (2011) [54] & $\begin{array}{l}\text { Used a three dimensional CFD } \\
\text { simulation to predict complex heat } \\
\text { transfer process and the } \\
\text { response variables. }\end{array}$ & $\begin{array}{l}\text { There was a small difference between } \\
\text { the numerical and experimental outputs } \\
\text { for the outlet of fluid temperature. }\end{array}$ \\
\hline
\end{tabular}


Table 1. Cont.

\begin{tabular}{|c|c|c|}
\hline Source & Description & Conclusion/s or Observation/s \\
\hline Javed et al. (2011b) [55] & $\begin{array}{l}\text { Measured the rest period for the } \\
\text { borehole needed after the test to return } \\
\text { to the initial ground temperature. }\end{array}$ & $\begin{array}{l}\text { The rest time increased with increases } \\
\text { both in the time and the rate of the } \\
\text { heat injection }\end{array}$ \\
\hline Meyer et al. (2011) [56] & $\begin{array}{l}\text { Installed a number of residential-size } \\
\text { ground source heat pumps in cold } \\
\text { climates to study the performance } \\
\text { of GSHPs. }\end{array}$ & $\begin{array}{l}\text { The ground source heat pumps were } \\
\text { found to be effective in cold climates, } \\
\text { and the COP varied between } 2.0 \text { and } 3.5 \text {. }\end{array}$ \\
\hline Garber-Slaght et al. (2014) [57] & $\begin{array}{l}\text { Installed a residential-size ground } \\
\text { source heat pump to study the impacts } \\
\text { of extracted heat over a period of three } \\
\text { months on the ground thermal } \\
\text { properties and any decline in heat pump } \\
\text { system efficiency. }\end{array}$ & $\begin{array}{l}\text { The results showed that the } \\
\text { surrounding soil temperature is higher } \\
\text { than the soil temperature around the } \\
\text { ground heat exchanger and the COP of } \\
\text { the heat pump was } 3.3 \text {. }\end{array}$ \\
\hline Lhendup et al. (2014) [58] & $\begin{array}{l}\text { Performed four field tests on two } \\
\text { boreholes with different depth to } \\
\text { evaluate the ground properties of GHEs. }\end{array}$ & $\begin{array}{l}\text { The field test results were compared } \\
\text { with results obtained from three } \\
\text { different methods. }\end{array}$ \\
\hline Shirazi and Bernier (2014) [59] & $\begin{array}{l}\text { Compared numerical and } \\
\text { experimental results. }\end{array}$ & $\begin{array}{l}\text { There were agreements between the } \\
\text { experimental and numerical results. }\end{array}$ \\
\hline Soriano et al. (2015) [60] & $\begin{array}{l}\text { Performed the first field to estimate the } \\
\text { soil thermal response in } \\
\text { Guayaquil, Ecuador }\end{array}$ & $\begin{array}{l}\text { The soil temperature was in the range of } \\
27 \text { to } 29^{\circ} \mathrm{C} \text {. }\end{array}$ \\
\hline Başer et al. (2015) [61] & $\begin{array}{l}\text { Carried out a field test to estimate the } \\
\text { distribution of undisturbed ground } \\
\text { temperature during the period a of heat } \\
\text { injection in underground thermal } \\
\text { energy storage system. }\end{array}$ & $\begin{array}{l}\text { The undisturbed ground temperature } \\
\text { was increased by } 7^{\circ} \mathrm{C} \text {. Four months } \\
\text { later, it was noticed that the heat storage } \\
\text { was decreased by } 60 \% \text {. }\end{array}$ \\
\hline Zhang et al. (2016) [62] & $\begin{array}{l}\text { Developed a novel transient quasi-3D } \\
\text { whole time scale line source model, } \\
\text { which characterized transient borehole } \\
\text { thermal resistance and examined the } \\
\text { heat flux profile along the two legs of } \\
\text { the U- tube. }\end{array}$ & $\begin{array}{l}\text { The modelling results were compared } \\
\text { with experimental sandbox. The errors } \\
\text { for the inlet and outlet fluid } \\
\text { temperature were less than } 5 \% \text {. }\end{array}$ \\
\hline Yu et al. (2017) [63] & $\begin{array}{l}\text { Investigated the performance of GSHPs } \\
\text { installed in } 24 \text { buildings in cold climate } \\
\text { zones of the United States (US). }\end{array}$ & $\begin{array}{l}\text { The overall performance of the GSHPs } \\
\text { used in cold climate regions was slightly } \\
\text { better }(\approx 6.1 \% \text { lower energy } \\
\text { consumption and } \approx 7.2 \% \text { lower in cost) } \\
\text { compared to the national median of } \\
\text { energy use and energy cost of typical } \\
\text { buildings of the same type } \\
\text { nationwide (US). }\end{array}$ \\
\hline
\end{tabular}

\section{Critical Observations}

This paper reviewed various experimental and numerical studies on closed-loop vertical ground heat exchangers (VGHEs). These studies indicate that several parameters such as fluid flow rate, thermal properties of the pipe and grout material, inlet and outlet pipe diameter, configuration of the pipes, etc. have significant impacts on the efficiency of ground source heat pumps (GSHPs). Several studies reported the use of numerical models to simulate the heat transfer process in VGHEs. Numerical models were found to be very useful tools to predict the performance and develop optimum design parameters for VGHEs. According to the studies reviewed in this paper, several design parameters can reduce the length of the borehole by increasing the efficiency of the borehole heat exchangers.

Grout is considered to be one of these parameters that has an effect on the efficiency of VGHEs. In the case of one particular experiment, the thermal resistance between the borehole wall and the heat carrier fluid decreased due to an increase in the thermal conductivity of the grout [12]. Another study found that depending on borehole diameter and soil thermal conductivity, the length of the borehole would decrease when the sand is added to cement-sand grout [13]. It was also reported that the thermal conductivity of the grout increases with the increase in soil density and moisture content 
during both heating and cooling cycles [14]. In certain geological conditions, groundwater can also similarly function as grout. The presence of natural convection flow in groundwater-filled borehole heat exchangers at different heat injection rates during thermal response tests was reported [17].

Borehole configuration also has an impact on the efficiency of ground heat exchangers. The thermal resistance for the double U-tube VGHEs with spacers was lower than the same without spacers [15]. Several studies reported that coaxial, double U-tube, spiral-tube and multi-tube boreholes had superior thermal performance compared to common single U-tube heat exchangers [29,32,35,37,48]. The thermal efficiency of coaxial borehole heat exchanger could be improved further by externally insulating the central pipe [29]. Triple-U type was found to be the best among all options (double-U, triple-U, double-W and spiral) for both thermal efficiency and cost of drilling [34]. The overall thermal efficiency could be increased by increasing borehole depth [26,46]. Higher thermal conductivity of the outer pipe would also increase the thermal efficiency of VGHEs [39].

Another important parameter that has an impact on the efficiency of the ground heat exchangers is borehole diameter. Larger borehole diameter and/or pipe diameter would lead to an increase in the thermal performance of VGHEs [36,49].

Based on the literature reviews presented in this paper, the borehole thermal resistance of VGHE could decrease within a range of $9 \%$ to $52 \%$ due to pipe configurations and characteristics of grout materials.

\section{Conclusions}

A comprehensive critical review on the efficiency of ground heat exchangers (GHE) in heat pump systems is presented in this paper. Increased efficiency of GHE reduces the depth of borehole and decreases the cost of installation. Hence, identification and optimization of construction and operation parameters that can reduce the borehole depth are among the most important design challenges. To deal with these challenges, various researchers conducted several studies to improve the heat transfer efficiency of GHEs. However, there are still opportunities for designers to suggest new pipe configurations that can increase the surface area of the pipe and heat transfer rate in GHEs.

Author Contributions: Conceptualization, A.E. and P.M.; investigation, A.E.; writing-original draft preparation, A.E. and P.M.; writing-review and editing, A.E. and P.M.; supervision, P.M.; All authors have read and agreed to the published version of the manuscript.

Funding: The graduate student (A.E.) was funded by the Libyan-North American Scholarship Program (LNASP), which is a joint collaboration between the Libyan Ministry of Higher Education and Scientific Research, the Canadian Bureau for International Education.

Conflicts of Interest: The authors declare no conflict of interest.

\section{References}

1. Ozturk, M. Energy and exergy analysis of a combined ground source heat pump system. Appl. Therm. Eng. 2014, 73, 362-370. [CrossRef]

2. ASHRAE. Heating, Ventilating, and Air-Conditioning Applications; American Society of Heating, Refrigerating and Air-Conditioning Engineers, Inc.: Atlanta, GA, USA, 2011.

3. Fashina, A.; Mundu, M.; Akiyode, O.; Abdullah, L.; Sanni, D.; Ounyesiga, L. The drivers and barriers of renewable energy applications and development in Uganda: A review. Clean Technol. 2019, 1, 9-39. [CrossRef]

4. Bishoge, O.K.; Zhang, L.; Mushi, W.G. The potential renewable energy for sustainable development in Tanzania: A review. Clean Technol. 2019, 1, 70-88. [CrossRef]

5. Omer, A.M. Ground-source heat pumps systems and applications. Renew. Sustain. Energy Rev. 2008, 12, 344-371. [CrossRef]

6. Sarbu, I.; Sebarchievici, C. General review of ground-source heat pump systems for heating and cooling of buildings. Energy Build. 2014, 70, 441-454. [CrossRef] 
7. Monzó, P. Comparison of Different Line Source Model Approaches for Analysis of Thermal Response Test in a U-Pipe Borehole Heat Exchanger. Master's Thesis, KTH School of Industrial Engineering and Management, Stockholm, Sweden, June 2011.

8. Mogensen, P. Fluid to duct wall heat transfer in duct system heat storages. Doc. Swed. Counc. Build. Res. 1983, 16, 652-657.

9. Eklöf, C.; Gehlin, S. TED-a Mobile Equipment for Thermal Response Test: Testing and Evaluation. Master's Thesis, Lulea University of Technology, Lulea, Sweden, June 1996.

10. Austin, W.A., III. Development of an In situ System for Measuring Ground Thermal Properties. Ph.D. Thesis, Oklahoma State University, Stillwater, OK, USA, May 1998.

11. Sanner, B.; Reuss, M.; Mands, E.; Müller, J. Thermal response test-experiences in Germany. In Proceedings of the Terrastock, Stuttgart, Germany, 28 August-1 September 2000; pp. 177-182.

12. Remund, C.P. Borehole thermal resistance: Laboratory and field studies. ASHRAE Trans. 1999, 105, 439.

13. Allan, M.L.; Kavanaugh, S.P. Thermal conductivity of cementitious grouts and impact on heat exchanger length design for ground source heat pumps. HVACER Res. 1999, 5, 85-96.

14. Abu-Hamdeh, N.H.; Khdair, A.I.; Reeder, R.C. A comparison of two methods used to evaluate thermal conductivity for some soils. Int. J. Heat Mass Transf. 2001, 44, 1073-1078. [CrossRef]

15. Pahud, D.; Matthey, B. Comparison of the thermal performance of double U-pipe borehole heat exchangers measured in situ. Energy Build. 2001, 33, 503-507. [CrossRef]

16. Katsura, T.; Nagano, K.; Takeda, S.; Shimakura, K. Heat transfer experiment in the ground with ground water advection. In Proceedings of the 10th Energy Conservation Thermal Energy Storage Conference Ecostock, Pomona, NJ, USA, 31 May-2 June 2006.

17. Gustafsson, A.M.; Westerlund, L. Multi-injection rate thermal response test in groundwater filled borehole heat exchanger. Renew. Energy 2010, 35, 1061-1070. [CrossRef]

18. Lee, C.; Park, M.; Min, S.; Kang, S.H.; Sohn, B.; Choi, H. Comparison of effective thermal conductivity in closed-loop vertical ground heat exchangers. Appl. Therm. Eng. 2011, 31, 3669-3676. [CrossRef]

19. Javed, S.; Spitler, J.D.; Fahlén, P. An experimental investigation of the accuracy of thermal response tests used to measure ground thermal properties. ASHRAE Trans. 2011, 117, 13-21.

20. Alrtimi, A.A.; Rouainia, M.; Manning, D.A.C. Thermal enhancement of PFA-based grout for geothermal heat exchangers. Appl. Therm. Eng. 2013, 54, 559-564. [CrossRef]

21. Lei, H.; Dai, C. Comparative experiment of different backfill grouts for concentric ground heat exchangers. Delta 2013, 37, 597-600.

22. Erol, S.; François, B. Efficiency of various grouting materials for borehole heat exchangers. Appl. Therm. Eng. 2014, 70, 788-799. [CrossRef]

23. Luo, J.; Rohn, J.; Xiang, W.; Bayer, M.; Priess, A.; Wilkmann, L.; Steger, H.; Zorn, R. Experimental investigation of a borehole field by enhanced geothermal response test and numerical analysis of performance of the borehole heat exchangers. Energy 2015, 84, 473-484. [CrossRef]

24. Choi, W.; Ooka, R. Effect of natural convection on thermal response test conducted in saturated porous formation: Comparison of gravel-backfilled and cement-grouted borehole heat exchangers. Renew. Energy 2016, 96, 891-903. [CrossRef]

25. Luo, J.; Tuo, J.; Huang, W.; Zhu, Y.; Jiao, Y.; Xiang, W.; Rohn, J. Influence of groundwater levels on effective thermal conductivity of the ground and heat transfer rate of borehole heat exchangers. Appl. Therm. Eng. 2018, 128, 508-516. [CrossRef]

26. Lee, C. Thermal performance evaluation of a vertical closed-loop ground heat exchanger according to rock type in Korea. Energy Build. 2019, 183, 184-194. [CrossRef]

27. Zeng, H.; Diao, N.; Fang, Z. Heat transfer analysis of boreholes in vertical ground heat exchangers. Int. J. Heat Mass Transf. 2003, 46, 4467-4481. [CrossRef]

28. Acuña, J.; Palm, B. A novel coaxial borehole heat exchanger: Description and first distributed thermal response test measurements. In Proceedings of the World Geothermal Congress, Bali, Indonesia, 25-30 April 2010; p. 7.

29. Guillaume, F. Analysis of a Novel Pipe in Pipe Coaxial Borehole Heat Exchanger. Master's Thesis, KTH School of Industrial Engineering and Management, Stockholm, Sweden, June 2011.

30. Beier, R.A.; Ewbank, G.N. In-Situ Test Thermal Response Tests Interpretations. OGEE Ground Source Heat Exchange Study; Oklahoma State University: Stillwater, OK, USA, 2012. 
31. Desmedt, J.; Van Bael, J.; Hoes, H.; Robeyn, N. Experimental performance of borehole heat exchangers and grouting materials for ground source heat pumps. Int. J. Energy Res. 2012, 36, 1238-1246. [CrossRef]

32. Acuña, J. Distributed Thermal Response Tests: New Insights on U-Pipe and Coaxial Heat Exchangers in Groundwater-Filled Boreholes. Ph.D. Thesis, KTH Royal Institute of Technology, Stockholm, Sweden, April 2013.

33. Bidarmaghz, A.; Narsilio, G.; Johnston, I. Numerical modelling of ground heat exchangers with different ground loop configurations for direct geothermal applications. In Proceedings of the 18th International Conference on Soil Mechanics and Geotechnical Engineering, Paris, France, 2-6 September 2013.

34. Dincer, S.; Erdogan, C.; ve Ticaret, B.B.M.S.; Beldesi, A.O. Experimental measurement and long term predictions of a multi-U tube borehole performance for ground source heat pumps. In Proceedings of the 11th IEA Heat Pump Conference 2014, Montréal, QC, Canada, 12-16 May 2014.

35. Haddada, J.; Miyara, A. Thermal performance and characteristics of spiral-tube ground heat exchanger for ground-source heat pump. In Proceedings of the International Heat Transfer Conference, Kyoto, Japan, 10-15 August 2014.

36. Haddada, J.; Miyara, A. Performance investigation of multiple-tube ground heat exchangers for ground-source heat pump. Am. J. Energy Eng. 2014, 2, 103-107.

37. Liu, X.; Xiao, Y.; Inthavong, K.; Tu, J. Experimental and numerical investigation on a new type of heat exchanger in ground source heat pump system. Energy Effic. 2015, 8, 845-857. [CrossRef]

38. Yoon, S.; Lee, S.R.; Xue, J.; Zosseder, K.; Go, G.H.; Park, H. Evaluation of the thermal efficiency and a cost analysis of different types of ground heat exchangers in energy piles. Energy Convers. Manag. 2015, 105, 393-402. [CrossRef]

39. Raymond, J.; Mercier, S.; Nguyen, L. Designing coaxial ground heat exchangers with a thermally enhanced outer pipe. Geotherm. Energy 2015, 3, 7. [CrossRef]

40. Chang, K.S.; Kim, M.J. Thermal performance evaluation of vertical U-loop ground heat exchanger using in-situ thermal response test. Renew. Energy 2016, 87, 585-591. [CrossRef]

41. Luo, J.; Zhao, H.; Gui, S.; Xiang, W.; Rohn, J.; Blum, P. Thermo-economic analysis of four different types of ground heat exchangers in energy piles. Appl. Therm. Eng. 2016, 108, 11-19. [CrossRef]

42. Sáez Blázquez, C.; Farfan Martin, A.; Martin Nieto, I.; Carrasco Garcia, P.; Sánchez Pérez, L.; González-Aguilera, D. Efficiency analysis of the main components of a vertical closed-loop system in a borehole heat exchanger. Energies 2017, 10, 201. [CrossRef]

43. Busso, A.; Georgiev, A.; Roth, P. Underground thermal energy storage-first thermal response test in South America. In Proceedings of the RIO 3-World Climate and Energy Event, Rio de Janeiro, Brazil, 1-5 December 2003; pp. 189-196.

44. Florides, G.; Kalogirou, S. First in situ determination of the thermal performance of a U-pipe borehole heat exchanger, in Cyprus. Appl. Therm. Eng. 2008, 28, 157-163. [CrossRef]

45. Sharqawy, M.H.; Said, S.A.; Mokheimer, E.M.; Habib, M.A.; Badr, H.M.; Al-Shayea, N.A. First in situ determination of the ground thermal conductivity for borehole heat exchanger applications in Saudi Arabia. Renew. Energy 2009, 34, 2218-2223. [CrossRef]

46. Esen, H.; Inalli, M. Thermal response of ground for different depths on vertical ground source heat pump system in Elaziğ, Turkey. J. Energy Inst. 2009, 82, 95-101. [CrossRef]

47. Beier, R.A.; Smith, M.D.; Spitler, J.D. Reference data sets for vertical borehole ground heat exchanger models and thermal response test analysis. Geothermics 2011, 40, 79-85. [CrossRef]

48. Acuña, J.; Palm, B. Distributed thermal response tests on pipe-in-pipe borehole heat exchangers. Appl. Energy 2013, 109, 312-320. [CrossRef]

49. Luo, J.; Rohn, J.; Bayer, M.; Priess, A. Thermal efficiency comparison of borehole heat exchangers with different drillhole diameters. Energies 2013, 6, 4187-4206. [CrossRef]

50. Cimmino, M.; Bernier, M. Experimental determination of the g-functions of a small-scale geothermal borehole. Geothermics 2015, 56, 60-71. [CrossRef]

51. Georgiev, A.G.; Popov, R.K.; Toshkov, E.T. In-situ measurements of ground thermal properties around borehole heat exchangers in Plovdiv, Bulgaria. Bulg. Chem. Commun. 2016, 48, 19-26.

52. Yavuzturk, C.; Spitler, J.D.; Rees, S.J. A transient two-dimensional finite volume model for the simulation of vertical U-tube ground heat exchangers. ASHRAE Trans. 1999, 105, 465-474. 
53. Li, Z.; Zheng, M. Development of a numerical model for the simulation of vertical U-tube ground heat exchangers. Appl. Therm. Eng. 2009, 29, 920-924. [CrossRef]

54. Khalajzadeh, V.; Heidarinejad, G.; Srebric, J. Parameters optimization of a vertical ground heat exchanger based on response surface methodology. Energy Build. 2011, 43, 1288-1294. [CrossRef]

55. Javed, S.; Claesson, J.; Beier, R. Recovery times after thermal response tests on vertical borehole heat exchangers. In Proceedings of the 23rd IIR International Congress of Refrigeration, Prague, Czech Republic, 21-26 August 2011.

56. Meyer, J.; Pride, D.; O’Toole, J.; Craven, C.; Spencer, V. Ground Source Heat Pumps in Cold Climates; Alaska Center for Energy and Power Cold Climate Housing Research Center: Fairbanks, AK, USA, 2011.

57. Garber-Slaght, R.; Daanen, P.R.; Roe, P.A. Ground source heat pump efficiency in cold climates. In Proceedings of the Conference Paper Session-Ground Source Heat Pump System, Seattle, WA, USA, 1 July 2014.

58. Lhendup, T.; Aye, L.; Fuller, R.J. In-situ measurement of borehole thermal properties in Melbourne. Appl. Therm. Eng. 2014, 73, 287-295. [CrossRef]

59. Salim Shirazi, A.; Bernier, M. A small-scale experimental apparatus to study heat transfer in the vicinity of geothermal boreholes. HVACER Res. 2014, 20, 819-827.

60. Soriano, G.; Villanueva, R.; González, I.; Montero, A.; Cornejo, M. First in situ measurement of soil thermal response in Guayaquil, Ecuador. WIT Trans. Ecol. Environ. 2015, 195, 327-336.

61. Başer, T.; Lu, N.; McCartney, J.S. Operational response of a soil-borehole thermal energy storage system. J. Geotech. Geoenviron. Eng. 2015, 142, 04015097. [CrossRef]

62. Zhang, L.; Zhang, Q.; Huang, G. A transient quasi-3D entire time scale line source model for the fluid and ground temperature prediction of vertical ground heat exchangers (GHEs). Appl. Energy 2016, 170, 65-75. [CrossRef]

63. Yu, Y.; Miao, R.; Miller, L.; Yang, H.; Olson, G. Recent Development and Application of Geothermal Heat Pump Systems in Cold-Climate Regions of the US: A Further Investigation. Engineering 2017, 9, 625. [CrossRef]

(C) 2020 by the authors. Licensee MDPI, Basel, Switzerland. This article is an open access article distributed under the terms and conditions of the Creative Commons Attribution (CC BY) license (http://creativecommons.org/licenses/by/4.0/). 